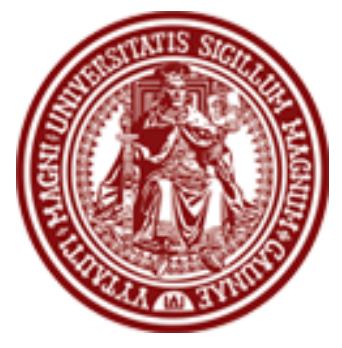

BALTIC JOURNAL OF LAW \& POLITICS

VOLUME 5, NUMBER 1 (2012)

ISSN 2029-0454

http://www.versita.com/bjlp

Cit.: Baltic Journal of Law \& Politics 5:1 (2012): 46-69

DOI: $10.2478 / \mathrm{v} 10076-012-0003-1$

\title{
ON THE POTENTIAL TO APPLY DE MINIMIS EXEMPTION FOR AGREEMENTS CONTAINING HARDCORE RESTRAINTS: EUROPEAN UNION PRACTICE
}

\author{
Andrius Puksas \\ Doctoral Candidate \\ Mykolas Romeris University, Faculty of Law (Lithuania) \\ Contact information \\ Address: Ateities str. 20, Vilnius LT-08303, Lithuania \\ Phone: (+370 5) 2714542 \\ E-mail address: andrius_puksas@mruni.eu; andrius.puksas@gmail.com
}

Received: May 11, 2012; reviews: 2; accepted: June 7, 2012.

\begin{abstract}
The article analyzes the possibility to apply de minimis exemption for agreements containing hardcore restraints. The statements are derived from analyses of scientific literature, relevant legislation, and the practice of courts and authorities responsible for competition maintenance.

Current European Union legislation excludes agreements containing hardcore restraints from applying de minimis exemption. The early practice of the European Court of Justice (hereinafter - ECJ) and the newest national courts' (e.g. Spain) decisions do not reflect this position. Furthermore, in 2010 the Netherlands broadened the application of de minimis exemption.

The article approaches a wide range of possibilities rather than the dogmatic practice of de minimis exemption. Besides the analysis of relevant jurisprudence, the article also assesses competition law specialists' opinions and possible solutions that proceed from the current situation.
\end{abstract}




\section{KEYWORDS}

Agreements, de minimis exemption, hardcore restraints, impact, competition 


\section{INTRODUCTION}

The current European Commission De Minimis Notice $^{1}$ provides priorities for the implementation of Article 101 of the Treaty on the Functioning of the European Union $^{2}$ (TFEU). This legal act establishes the common rule that any agreements, decisions or actions that interfere with natural competition or have the aim to effect, restrict or distort competition, are prohibited. The provisions of the Notice (point 3) should be applicable in order to assess the agreement's impact on competition, and not to effect trade between Member States.

This legal act, derived from ECJ practice, rehabilitates agreements which do not appreciably restrict competition. It provides conditions which should fulfill horizontal (between competitors), vertical (between non-competitors) and mixed (difficult to determine if the parties are competitors or not) agreements in order to apply de minimis exemption. It stipulates that agreements which have a minor impact on competition maintain legally binding force between their parties. The national legal acts also have analogical provisions. Article 5 of the Lithuanian Competition law $^{3}$ prohibits agreements which have a restrictive impact on competition. In Lithuania, de minimis exemption is provided by the Competition Council resolution No. $15-172^{4}$ in 2004. Point 11 of the Notice and items 7-9 of Resolution No. 1S-172 provide "exception from exemption" - the rule is not applicable for agreements containing hardcore restraints. The Article 101(3) of TFEU $^{5}$ can be applied in an exceptional situation. For instance, it could be applied in cases of temporary restriction of active (desire to get back investments) and passive (desire to get in to new markets) sales ${ }^{6}$.

Discussion about de minimis application for agreements containing hardcore restraints has been relevant for quite a while now. It has been partly addressed by prof. Alison Jones ${ }^{7}$ and prof. Richard Whish ${ }^{8}$. In an article related to hardcore

\footnotetext{
${ }^{1}$ Notice (December 22, 2001) on agreements of minor importance which do not appreciably restrict competition under Article 81(1) of the Treaty establishing the European Community (de minimis), European Commission, Official Gazette (2001, no. 368/07).

${ }^{2}$ Consolidated Version of the Treaty on the Functioning of the European Union, Official Gazette (2008, no. C 115/47).

${ }^{3}$ Law on Competition of the Republic of Lithuania, Official Gazette (1999, no. 30-856).

${ }^{4}$ Resolution no. 1S-172 (December 9, 2004) on Approval of Requirements and Conditions in Respect of Agreements of Minor Importance which do not Appreciably Restrict Competition, Competition Council of the Republic of Lithuania, Official Gazette (2004, no. 181-6732).

${ }^{5}$ Van Bael \& Bellis, Competition Law on the European Community (Kluwer Law International, 2005), p. 85.

${ }^{6}$ Lennart Ritter and David W. Braun, European Competition Law: A Practitioner's Guide, Third Edition (Kluwer Law International, 2004), p. 225.

7 Alison Jones and Brenda Sufrin, EU Competition Law. Text, Cases, and Materials, Fourth Edition (New York: Oxford University press, 2011), p. 172.

${ }^{8}$ Richard Whish, Competition Law, Sixth Edition (New York: Oxford University press, 2009), p. 117.
} 
restraints $^{9}$ prof. A. Jones proposes the application of de minimis. A national competition law specialist, assoc. prof. Daivis Švirinas ${ }^{10}$ expressed his opinion on the possibility to apply de minimis for agreements on recommended resale prices, whereas resale price maintenance does not fall under conditions to apply this exemption. The issue is not a new one; however, no effective solutions have been found yet. The problem is also relevant because in different EU countries de minimis application for agreements containing hardcore restraints is regulated differently, therefore analogical agreements in separate jurisdictions can have various outcomes; de minimis exemptions are either applied or unconditionally prohibited.

Using document analysis, and systemic and comparative analysis, this article analyzes and assesses the possibility to apply de minimis exemption for agreements containing hardcore restraints. The set tasks are to analyze EU and national practices of applying de minimis exception for agreements containing hardcore restraints, to assess the current regulation and make proposals for further possible changes in legislation.

The article is divided into two sections. The first analyzes the roots of de minimis exemption and current opinions on its applicability. Further the article addresses the problem of exemption's inapplicability for agreements containing hardcore restraints and gives the definition of such restrictions. The section ends with a reference to agreements' relation to Article 101 of TFEU. The second section is dedicated to the practice of applying de minimis exemption. The article points out important assessment criteria, analyzes the order of assessment process and the possibility to apply de minimis exemption which is granted by some EU members legislation. Finally, relevant amendments to current regulation are offered.

\section{THE CONDITIONS TO APPLY DE MINIMIS EXEMPTION}

In legal regulations de minimis exemption can be found as early as 1969 . The ECJ settled a case between the owner of the washing machines company "Erd \& Co" producer Mr. Völk and "Vervaecke", dealers of household appliances in Belgium and Luxembourg. The agreements' restrictive provisions became the basis for this case. Despite those provisions ECJ decided that the weak position of the parties in this market made a minor impact on competition ${ }^{11}$. This decision allows us to agree with London King's College prof. Alison Jones and Bristol University prof. Brenda Sufrin's

\footnotetext{
${ }^{9}$ Alison Jones, "The Journey Toward an Effects-based Approach under Article 101 TFEU - The Case of Hardcore Restraints," The Antitrust bulletin Vol. 55, No. 4 (Winter 2010): 808.

10 Daivis Švirinas, "The Peculiarities of the Assessment of the Use of Recommended Resale Prices under Article 81 of the European Community Treaty," Social Sciences Studies (2010) No. 1(5): 219-236.

${ }^{11}$ Völk v. Vervaecke, European Court of Justice (1969, no. 5/69).
} 
opinion that even agreements containing hardcore restraints can have a minor impact on competition. The main condition for determining that impact is to define the weak agreements participants' position in the market. The harder the restraint, the weaker the position of the agreements parties in the market should be. ${ }^{12}$ The case 'Völk $v$ Vervaecke' is important for several reasons:

- de minimis exemption was applied for the first time;

- the exemption was applied for agreement containing hardcore restraint (absolute territorial protection for the distributor).

There is no basis for prohibiting the agreements which have just a minor effect on competition. Agreements that do not have a significant impact on the market could not be lively and supposed to be affected by markets' self-regulation mechanism(s). They also do not harm consumers and other subjects, which is easy to explain: customers may still choose from a wide range of products and services. All agreements where the parties do not have "the market power" should be assessed in order to apply de minimis exemptions. Only agreements with considerable effect on competition should be prohibited. It is presumed that agreements containing hardcore restraints are more dangerous ${ }^{13}$, so the assessment rules for them should be stricter.

Professor Richard Whish also agrees with colleagues about the necessity to assess such agreements in order to apply exception:

The de minimis doctrine applies both to agreements whose object and whose effect is to prevent competition, which means that even horizontal restraints of a clearly anti-competitive nature or export bans in a vertical agreements could fall outside Article $101^{14}$ because of their diminutive impact; having said this, it is to be expected that a stricter approach will be taken to agreement in the 'object' category within Article $101(1)^{15}$ than those that have as their effect the restriction of competition. ${ }^{16}$

Why did the question about the assessment of agreements containing hardcore restraints arise in the first place? According the Article 101 of TFEU, such agreements are prohibited and their parties should be punished severely. The problem occurs when, based on de minimis exemption, some of the agreements can be rehabilitated as they do not have considerable effect on competition, whereas agreements containing hardcore restraints are condemned to attain strict sanctions despite their weak impact on competition. Is intervention of the

\footnotetext{
${ }^{12}$ Alison Jones and Brenda Sufrin, supra note 7, p. 172.

13 Richard Whish, supra note 8: 652-653.

${ }^{14}$ Original text refers to Article $81(1)$ of Treaty Establishing the European Community. Currently its content is reflected in Article 101(1) TFEU.

${ }^{15}$ Ibid.

${ }^{16}$ Richard Whish, supra note 8, p. 138.
} 
competent authorities always necessary? Monitoring in accordance with legal acts should be provided at all times, but the action should be taken only when the effect on competition is not minor. If the parties of the agreement are relatively small in their relevant market(s), then the cartel would be too brittle and lifeless, which would result in continuous agreement violations. The market itself has a way to solve the matters of such cartels (namely, self-regulation). As a rule, markets' selfregulation has a negative impact on such parties' process.

Hardcore restraints are restrictions related by object. "Restrictions of competition by object are those that by their very nature have the potential to restrict competition within the meaning of Article 101(1). It is not necessary to examine the actual or potential effects of an agreement on the market once its anti-competitive object has been established." ${ }^{17}$ Such a position by the European Commission could become a barrier for individual assessment of agreements with restriction by object and application of de minimis. Is it enough to determine the type of restriction? Or it is necessary to assess the significance of the agreement's impact on competition? The answer to the first one is negative, automatically giving a positive response to the second. The provision by the European Commission legal act should be explained in more detail. It should be presumed that determination of restriction by object signals that impact on competition exists. But this is just the first step. The next compulsory step is to measure the detected impact. There is no question whether the agreement containing hardcore restraints distorts competition-it seemingly always has a negative impact on it. The question is whether it is beneficial and effective to prohibit such agreements.

Which restraints are involved in a so-called blacklist and are therefore named hardcore? We can find the exemplary list not only in the de minimis Notice (point 11) but also in jurisprudence ${ }^{18}$ :

- $\quad$ agreements between competitors to fix prices, limit output or share markets;

- $\quad$ agreements between competitors to reduce capacity;

- information exchange designed to fix purchase or sale prices;

- vertical restraints conferring an exclusive sales territory and protection from sales by others within the territory (absolute territorial protection or ATP) or otherwise prohibiting or limiting parallel trade;

- $\quad$ vertical restraints imposing fixed or minimum resale prices on a dealer (resale price maintenance or RPM). ${ }^{19}$

17 Communication (January 14, 2011) on Guidelines on the Applicability of Article 101 of the Treaty on the Functioning of the European Union to Horizontal Co-operation Agreements, European Commission, Official Gazette (2011, no. C 11/01), para. 24.

${ }_{18}$ Alison Jones, supra note 9: 795-796; for example T-Mobile Netherlands BV, KPN Mobile NV, Orange Nederland NV, Vodafone Libertel BV v. Raad van bestuur van de Nederlandse Mededingingsautoriteit, European Court of Justice (2009, no. 8/108), para. 36-43, European Night Services v. Commission, The Court of First Instance (1998, Case T-374/94), para 136. 
There is no doubt that it is impossible to prepare a complete and exhaustive list of hardcore restraints. The contents of the list (including new and excluding existing restraints) are open for jurisprudence. "An agreement may be regarded as having a restrictive object even if it does not have the restriction of competition as its sole aim but also pursues other legitimate objectives." 20

At the beginning of 2011 guidelines for horizontal co-operation agreements ${ }^{21}$ entered into force. In this legal act the European Commission pays more attention to agreements which restrict competition but do not contain hardcore restrictions. This category includes selective distribution agreements, but also agreements to maintain prices. Price-fixing is considered to have the goal of limiting competition despite the fact of joint distribution. ${ }^{22}$ Nevertheless, two small economic units (for example two kiosks or other small selling places) cannot damage competition with their agreement.

The less there are restrictions by object, the more flexible the assessment is; usually only quantitative criteria (parties' share of the market) are taken into account. The quantitative criteria will be discussed further. "The distinction between 'infringements by object' and 'infringements by effect' arises from the fact that certain forms of collusion between undertakings can be regarded, by their very nature, as being injurious to the proper functioning of normal competition." ${ }^{23} \mathrm{De}$ minimis exemption is not applied for agreements containing hardcore restraints because of the increased harmfulness which is presumed to be caused by them ${ }^{24}$. For example, an agreement containing price-fixing restraints limits price competition. According to economists price competition maintains prices at the lowest possible level and encourages the trade of goods between member states. Also it creates the possibility for optimal resource distribution and provides a wide range of products and services for the customers. ${ }^{25}$ It is obvious that steps to make penalties more severe were connected with customer rights protection. Whereas steps that include application of de minimis exemption demonstrated the desire to

${ }^{19}$ Ibid.

${ }^{20}$ Competition Authority v. Beef Industry Development Society Ltd and Barry Brothers (Carrigmore) Meats Ltd, European Court of Justice (2008, no. C-209/07), para. 21, General Motors BV v. Commission of the European Communities, European Court of Justice (2006, no. C-551/03), para. 64, and T-Mobile Netherlands BV, KPN Mobile NV, Orange Nederland NV, Vodafone Libertel BV v. Raad van bestuur van de Nederlandse Mededingingsautoriteit, supra note 18.

${ }^{21}$ Communication (January 14, 2011) on Guidelines on the Applicability of Article 101 of the Treaty on the Functioning of the European Union to Horizontal Co-operation Agreements, supra note 17.

${ }^{22}$ Lars Kjølbye, "Escaping Effects Analysis: The Commission's New Approach to Restrictions by Object," CPI Antitrust Journal: Covington \& Burling LLP (2011 (1)).

${ }^{23}$ Competition Authority v. Beef Industry Development Society Ltd and Barry Brothers (Carrigmore) Meats Ltd, supra note 20.

${ }_{24}$ Richard Whish, supra note 8, p. 652-653.

${ }^{25}$ ICI v. Dyestuffs (Commission), European Court of Justice (1972, no. 48/69), para. 115, and Lennart Ritter, and David W. Braun, supra note 6, p. 169. 
strike a balance between the interests of customers and economic units. The latter, or "principle of scales", is more convenient for free market economies.

The assumption that agreements containing hardcore restraints can be assessed only in accordance with Article 101(3) is misleading. It is also possible to assess them in accordance with the de minimis rule. Some amendments to current regulation are suggested here. The most convenient and rational approach is to abolish provisions binding the possibility to apply de minimis for agreements containing hardcore restraints. Furthermore, provisions with more severe criteria should be added to the current regulations (de minimis Notice, national legal acts). The ECJ has approved such changes but the European Commission still supports a stricter position.

Article 101(3) of TFEU provides exceptions for agreements which have procompetitive impact (technical or economical progress, benefits for customers). Such agreements cannot impose unnecessary restrictions in order to achieve results and cannot abolish the competition significantly. If there is no possibility to apply the exemption imposed in Article 101(3), the possibility to assess agreement in accordance with the de minimis rule still exists.

\section{THE PRACTICE OF APPLYING DE MINIMIS EXEMPTION FOR AGREEMENTS CONTAINING HARDCORE RESTRAINTS}

The appearance of de minimis exemption and its application allowed institutions responsible for supervising competitive situations to pay more attention to more serious problems (for example agreements between larger economic units). It also provides the conditional safety for smaller economic units. The European Commission supports the position that this exemption should not be applied for agreements containing hardcore restraints. This position is also reflected in the de minimis Notice. But the statement that additional assessment is expensive (it consumes time, financial and other resources) should be rejected. In all cases the competent institutions should carry an assessment process. For example, this could be important before imposing fines. Maybe this assessment is not always detailed, but it is still necessary. The result of this process can be useful in order to protect agreements between small economic units from the threat of unreasonable prohibition. That is why in each and every case the penalty should be related to the harmfulness of the agreement. It is impossible to determine this without an analysis, since every single situation is different because of various levels of impact on competition. 
As far back as 1969 the ECJ set a precedent ${ }^{26}$ according to which agreements containing hardcore restraints (agreements granting absolute territorial protection) can also be considered as having a minor impact. Unfortunately the European Commission supports a different approach, which obvious disadvantages were noted by prof. A. Jones:

Despite the clear rulings of the ECJ on the position regarding contracts incorporating hardcore restraints, however, the Commission excludes such agreements from the benefit of the guidance. Although the mere fact that the Commission's Notice does not apply to these agreements does not affect their legality, their exclusion from the Notice creates greater uncertainty on this issue. Commission guidance on the question of when such agreements would be likely to escape violation of Article 101(1) on this ground would clearly be very useful in practice. ${ }^{27}$

There is no need to declare such guidance to be a separate legal act. Corresponding provisions should find their place in the new de minimis Notice. Why create a new legal act when amendments can be adopted in a current one? The possibility to apply exception could be added to point 11 of the de minimis Notice. National institutions can stay flexible in each situation - Notice and its provisions have the force of recommendation, not obligation.

There are no doubts that regulations concerning agreement assessment in accordance with Article 101 of TFEU need to be reviewed and changed. The same can be said about the Council Regulation (EC) No 1/2003: "Agreements, decisions and concerted practices caught by Article $81(1)$ of the Treaty which do not satisfy the conditions of Article 81(3) of the Treaty shall be prohibited, no prior decision to that effect being required. ${ }^{28}$ This provision can be misleading because of the possibility not to apply the de minimis exemption. The possible amendments to Regulation (EC) No 1/2003 are:

- to change the provision concerning prohibition of agreements caught by Article 101(1) TFEU and which do not satisfy the conditions of Article 101(3) TFEU adding a possibility to apply exception, or

- $\quad$ to give a direct reference to the de minimis Notice.

It should be noted that the position concerning the rehabilitation of agreements containing hardcore restrictions is changing. Those changes also partly reflected in legal acts. For instance, paragraph 8 of current Guidelines on Vertical Restraints states: "Agreements that are not capable of appreciably affecting trade

\footnotetext{
${ }^{26}$ Völk v. Vervaecke, supra note 11.

${ }^{27}$ Alison Jones, supra note 9: 808.

${ }^{28}$ Regulation no. 1/2003 (December 16, 2002) on implementation of the rules on competition laid down in Articles 81 and 82 of the Treaty, European Council, Official Gazette (2003, no. L 1), chap. 1, art. 1.; Articles 81(1) and 81(3) currently are reflected in Article 101(1) and Article 101(3) TFEU.
} 
between Member States or of appreciably restricting competition by object or effect do not fall within the scope of Article 101(1)."29 Despite the goals which were set by the parties of the agreement, it will escape the application of Article 101(1) if the impact on competition will be insignificant. Such regulation meets the provisions stated in the Notice of 2001 for agreements which do not contain hardcore restraints. What schemes for implementing exception can be suggested?

- De minimis exemption is applicable for all agreements while they do not exceed fixed share of market. If a significant impact on competition is determined, permission for particular agreement could be abolished;

- The legal acts, regulating application of de minimis exemption could be supplemented with a provision, according to which exemption could also be applied to agreements containing provisions from the so called blacklist. The main condition is not to have significant impact on competition. In this case the burden of proof could be transferred to the parties of a particular agreement.

The latter option is more convenient because of its simpler implementation.

\subsection{THE IMPORTANT ASPECTS OF AGREEMENT ASSESSMENT IN ACCORDANCE WITH THE DE MINIMIS RULE}

Each agreement should be assessed individually in accordance with legal and economical criteria. During this process it is important to take into account "the content of the agreement, the objectives it seeks to attain, and the economic and legal context of which it forms part". ${ }^{30}$ The assessment of agreement cannot end after the determination of hardcore restraints. The precise determination of the agreement's impact on competition is also important for setting sanctions for agreement's parties. In exceptional situations it can lead to application of the de minimis exemption. During the assessment process quantitative and qualitative criteria are both important. An agreement's participants' share in the relevant market has to be determined (both product and geographical market). Other criteria, such as economic and other links between the parties, are also important. The circumstances before and after the agreement enters into force should also be assessed, as well as whether the parties' actions had significant impact on competition. The agreement's parties' importance in the relevant market is determined in several ways: mostly the turnover (sales) rates are compared with

${ }^{29}$ Guidelines (May 19, 2010) on Vertical Restraints, European Commission, Official Gazette (2010, no. C 130/01).

${ }^{30}$ Communication (January 14, 2011) on Guidelines on the Applicability of Article 101 of the Treaty on the Functioning of the European Union to Horizontal Co-operation Agreements, supra note 17, para. 25. 
the turnover of other economic units ${ }^{31}$. Market research can be useful, as well as information received from the agreement's parties. ${ }^{32}$ The rates of sales can also be reflected by physical (homogeneous goods) or value (heterogenic goods) expressions. ${ }^{33}$

It is important to determine if the assessed agreement is a horizontal, mixed or vertical one. The first two types are presumed to be more dangerous ${ }^{34}$. The anticipated market barrier (quantitative criteria) is lower for the first two types ${ }^{35}$. A systematic explanation allows us to adapt this rule to agreements containing hardcore restraints. In such cases quantitative criteria for vertical agreements should be less strict. There are even more ambitious suggestions. For instance, Greek lawyer Nikolaos Verro proposes the exclusion of resale price maintenance from the list of hardcore restraints which is inscribed in the de minimis Notice ${ }^{36}$. It would be more rational to keep the current list of hardcore restraints due to the harm caused by the situation when one party cannot set prices without the confirmation of the other. Hardcore price fixing restricts competition. Of course the situation is different when it has a recommendation character and parties are able to set prices independently from one another. Assoc. prof. D. Švirinas was right to note that it is important to take into account if the quantitative criteria are satisfied when the situation of 'recommended prices application' is being assessed ${ }^{37}$. It is also important not to confuse recommended prices for fixed prices. There is no doubt that an agreement has anti-competitive impact when it is agreed to maintain resale prices by setting minimal or fixed prices ${ }^{38}$. In such a situation it would be possible to consider the rehabilitation option right after individual economic analysis. One of the options is to set in the de minimis Notice the separate quantitative and qualitative assessment criteria and to apply them for restraints from the blacklist. The presumption concerning the higher danger of some restraints (such as price fixing) appeared for a reason. The exemplary list could be useful not just for authorities responsible for competition situation monitoring but also for economic units. For the latter it can provide the possibility to assess

\footnotetext{
${ }^{31}$ Lennart Ritter and David W. Braun, supra note 6, p. 42.

32 Notice (December 9, 1997) on the definition of relevant market for the purposes of Community competition law, European Commission, Official Gazette (1997, no. 372/03), para. 53-55.

${ }^{33}$ Resolution no. 17 (February 24, 2000) Concerning Explanations of the Competition Council on the Definition of the Relevant Market, Competition Council of the Republic of Lithuania, Official Gazette (2000, no. 19-487), p. 32.

${ }^{34}$ Guidelines (May 19, 2010) on Vertical Restraints, supra note 29, p. 6.

35 Notice (December 22, 2001) on agreements of minor importance which do not appreciably restrict competition under Article 81(1) of the Treaty establishing the European Community (de minimis), supra note 1 , p. 7.

36 Nikolaos Verras, "Resale Price Maintenance in E.U. Competition Law: Thoughts in Relation to the Vertical Restraints Review Procedure," The Columbia Journal of European Law Online 37 (2009) // http://www.cjel.net/online/16_1-verras/ (accessed June 10, 2011), and Nikolaos Verras, "Developments in Vertical Agreements," The Antitrust bulletin Vol. 55, No. 4 (Winter 2010): 872.

${ }^{37}$ Daivis Švirinas, supra note 10: 231-234.

${ }^{38}$ Ibid.
} 
perspectives of upcoming agreement before or during the consideration process. New provisions have the strong potential to be a tool for preventative goals.

Each agreement assessment process is based on an analysis of presently existing and possible (future) consequences. Presumptions stipulated in the de minimis Notice were based on common economic analysis. The same is to be said about the presumptions concerning the increased severity of some restraints. Presumption is considered to be correct until it is denied. Economic analysis plays an important role in three fields: improving current regulations, analyzing individual cases and analyzing situation after intervention. ${ }^{39}$ It helps to distinguish some provisions for applying or not applying the exception. Nevertheless, a presumption cannot restrict the competence of authorities responsible for agreement assessment. Each agreement should be assessed in accordance with its individual features.

Why does the European Commission not provide for the possibility of applying de minimis exemption for agreements containing hardcore restraints? The problem is more complicated than it may at first appear. Professor of law from Charles University (Prague, Czech Republic) Luboš Tichý asserts that modernization of Article 101 of TFEU requires the per se rule to be reformed. It could be fulfilled by taking into account the economic facts and predictions. ${ }^{40}$ Per se is criticized for its formality and ignorance towards pro-competitive agreements. According to some critics, there is no need to create something new. There were some suggestions to apply the rule of reason doctrine in the EU competition law, as was successfully implemented in the USA. It recalls the 'principle of scales', where all important arguments are weighed (for example proportion between the positive and negative effect is determined). I support this position. The rule of reason doctrine can be useful not only weighting positive and negative effects of an agreement but also when assessing significance of the impact.

What changes would appear after fully changing per se or partly involving the rule of reason?

- Per se requires applying restriction provided by Article 101(1) of TFEU automatically when hardcore restraint is determined in an agreement. Possible exception - Article 101(3) of TFEU;

- rule of reason allows the application of Article 101(1) of TFEU or de minimis exemption. The option depends on the results of economic analysis.

Supporters of the rule of reason doctrine warn that in this case the test of significance should not be confused with the wider rule of reason doctrine in the

\footnotetext{
39 Josef Drexl, Laurence Idot, and Joel Maneger, Economic Theory and Competition Law, Academic Society for Competition Law (Edward Elgar Publishing Limited, 2009), p. 3.

40 Ibid., p. 72.
} 
USA. The latter focuses on analysis and overall assessment of the relevant facts ${ }^{41}$. The use of a narrower version of rule of reason doctrine in Europe is suggested. However, it is not disclosed just how much narrower this should be. One thing can be stated for sure - all factors important for an individual case should be weighed.

The fact that there is no need to prove that some restraints impose restriction on competition does not contradict the possibility to apply de minimis exemption. The latter is applicable precisely for agreements containing restraints. The main criteria are not the type of restraint but its scale. The assessment of agreements with restraints by object can be complicated if it contains several hardcore restraints (for example sharing the market and price fixing). Nonetheless, such practice is not unusual; significant part of agreements contain at least a couple restrictions from the blacklist ${ }^{42}$. But this does not mean that such agreements should automatically be prohibited in accordance with Article 101(1) of TFEU. In such cases they also have to be assessed individually. The assessment will likely prove the assumption that even while containing restraints, an agreement cannot significantly restrict competition if the parties of agreement are quite small in their relevant market(s).

What is the difference between agreement assessment in accordance with Article 101(3) of TFEU and de minimis? As already noted, the first rule allows the rehabilitation of agreements containing hardcore restraints because of their procompetitive impact. The goal of assessment in accordance with Article 101(3) of TFEU is to determine the balance between the benefits of an agreement and its harmfulness. It partly corresponds to the above proposed rule of reason doctrine. The goals of an institution performing assessment are to determine if the negative impact is higher or lower in comparison with the benefits. As a rule, in accordance with the Article 101(3), cooperation agreements are assessed. Their parties usually combine their resources to achieve pro-competitive goals. For instance, the goal of cooperation can be the intention to create a new product which would be useful for customers. Before applying de minimis it is important to measure the agreement's impact on competition. It is determined by the assessing qualitative (for example, if there are hardcore restraints or not) and quantitative (for instance, the shares of the market, the size of the agreement's participants) criteria but not by measuring the agreement's benefits. There is no need to determine the positive impact - it is enough to state that the agreement does not significantly harm competition.

\footnotetext{
${ }^{41}$ Lennart Ritter and David W. Braun, supra note 6, p. 127.

${ }^{42}$ Richard Whish, supra note 8, p. 509-510.
} 


\subsection{AGREEMENT ASSESSMENT CRITERIA: FROM CURRENT REGULATIONS TO POSSIBLE FUTURE AMENDMENTS}

The negative impact on competition is connected with the threat of such an agreement. Smaller market shares held by the parties lead to the agreement's lesser impact on the market, thus the danger is presumed to be lower too. The critics of current regulation propose to apply Article 101(1) of TFEU "to fewer agreements: only those agreements that posed a real threat to competition should be caught in the net of competition law; other should not be ensnared by competition rules at all". ${ }^{43}$ Until the established border is crossed, agreements cannot distort competition significantly. This position is reflected in the de minimis Notice where qualitative (for example if there are hardcore restrictions) and quantitative assessment criteria are imposed. This legal act provides such quantitative criteria (borders) ${ }^{44}$ :

- In case of horizontal and mixed agreements the market share for its parties is up to 10 percent (all participants together);

- In case of vertical agreements the market share is up to 15 percent (for each participant separately).

As a rule, assessment is conducted comparing individual market share with the one imposed in legal acts. When applying 'relevant market shares borders' to agreements containing hardcore restraints it is necessary to take into account the fact that vertical agreements are presumed to be less dangerous than horizontal and mixed ones. The systematic interpretation should cause this differentiation. It can be illustrated:

- In case of horizontal and mixed agreements containing hardcore restrictions, up to 1 percent of joint market share for its parties (all participants together);

- In case of vertical agreements containing hardcore restrictions, up to 1,5 percent of separate market share for its parties (for each participant separately).

The numbers above suggest one possible way to distinguish the threat of such agreements. Legal amendments have to be based on recent jurisprudence and the practice of institutions responsible for evaluating competition, as well as on opinions of economists.

The separate criteria do not contradict with the possibility to apply rule of reason doctrine or some features of it - the criteria will help measure restrictions and will not create barriers for reasonable de minimis application. The 'principle of

\footnotetext{
43 Ibid., p. 114.

${ }^{44}$ Notice (December 22, 2001) on agreements of minor importance which do not appreciably restrict competition under Article 81(1) of the Treaty establishing the European Community (de minimis), supra note 1 , point 7.
} 
scales' is based more on probabilities; for instance two percent of joint market share for horizontal agreement could be presumed as having significant impact on competition.

De minimis Notice provides more presumptions: agreements between small and medium-sized undertakings are rarely capable of considerable effect on competition (point 3). Some of them are also provided in points $8-9$. It can be stated that the first presumption is closely related with the possibility to apply de minimis exemption for agreements containing hardcore restraints. Restraints from the blacklist are rarely capable of distorting competition in the relevant market if the parties of agreement are small or medium-sized undertakings. As a rule they are too small (for instance, kiosks) to cause significant reflection in the relevant market.

All the criteria mentioned above are only presumptions. Point 2 in the Notice provides us with a more flexible approach: if the share of participants in the relevant market exceeds the thresholds it does not automatically mean that the agreement considerably distorts competition. An adverse position is also available: if the borders have not been reached, the agreement can still restrict competition significantly. This means that criteria imposed by legal acts are only tentative. For successful application of de minimis for agreements containing hardcore restraints it is enough to make corrections in point 11 in the Notice. For instance "points 7, 8 and 9 do not apply to agreements containing any of the following hardcore restrictions" can be changed with a new provision that agreements containing restraints listed in points 7-9 can be excused by de minimis. However, in cases of restraints by object criteria, in order to excuse, the restraints must be stricter. This is only one of the available options. Nevertheless, setting some tentative quantitative criteria for the agreement's parties' share in the market is a better way to resolve the issue.

When conducting the assessment process it is important to take into account all essential criteria. There is no doubt that in each situation they can be different. For instance, according to new horizontal cooperation guidelines:

Factors such as whether the parties to the agreement have high market shares, whether they are close competitors, whether the customers have limited possibilities of switching suppliers, whether competitors are unlikely to increase supply if prices increase, and whether one of the parties to the agreement is an important competitive force, are all relevant for the competitive assessment of the agreement. ${ }^{45}$

45 Communication (January 14, 2011) on Guidelines on the Applicability of Article 101 of the Treaty on the Functioning of the European Union to Horizontal Co-operation Agreements, supra note 17, para. 34. 
It should be noted that parties of cooperation agreements can frequently expect the application of Article 101(3) of TFEU. In legal acts, the stipulating criteria for cooperation agreements are also applicable for cartel agreements, which have distortion or competition restriction as their goal.

Analysis of common practice has shown that competent institutions responsible for agreement assessment are paying particular attention to defining the relevant market, determining the shares of agreement parties and comparing them with quantitative criteria from the de minimis Notice. It should be noted that, despite the variety of restraints, the determined maximum border of the market is the same. The order of assessing agreements containing hardcore restraints should be the following:

- Determining that agreement contains hardcore restraints;

- $\quad$ Defining the relevant (product and geographic) market;

- Determining market shares of agreement's parties (they should be different from the ones that are set for agreements that do not include any hardcore restraints; for instance up to 1,5 percents);

- Determining if the position of agreements parties and agreements provisions have significant impact on competition.

\subsection{APPLYING DE MINIMIS FOR AGREEMENTS CONTAINING} HARDCORE RESTRAINTS: EU PRACTICE

The Dutch are mentioned among the first ones whose national legal acts attempted to rehabilitate agreements containing hardcore restraints with reference to their insignificant impact on competition. Such determined actions of legislators in the Netherlands caused fierce discussions about their compatibility with EU law provisions. But what really happened? Since 1997 (until 2010), some provisions were stricter in Netherlands Competition $\operatorname{law}^{46}$ than the ones in the European Commission's Notice of 2001. In a national legal act, a five percent quantitative threshold was imposed for the agreement's parties' market share. The amendment has widened it to ten percent, but it did not separately mention agreements containing hardcore restraints.

The situation when an agreement should be prohibited by the Article 101(1) TFEU, but national legal act ${ }^{47}$ rehabilitates it, became the center of discussion. The

\footnotetext{
${ }^{46}$ Law on Competition of the Kingdom of the Netherlands, 1997 [with amendments which entered into force after July 1, 2009] // http://www.dutchcivillaw.com/legislation/competitionact.htm (accessed June $10,2011)$.

47 "Beware of legal privilege?! Dutch de minimis exemption for hardcore infringements in line with EU law," Competition Newsletter, De Brauw Blackstone Westbroek (February 2011) // http://www.debrauw.com/SiteCollectionDocuments/Legal\%20Alerts/Competition/Competition\%20Newsl etter\%20February\%202011.html (accessed June 15, 2011).
} 
basis for legal disputes is the same quantitative criteria for agreements containing hardcore restraints and ones that do not include such restraints. More suggestions to take into account the different scale of threat of hardcore restraints have risen since such provisions entered into force. Those suggestions emerge from the fear that new provisions contradict the practice of implementing Article 101 of TFEU.

It would be a mistake to state that the model chosen by the Dutch can help agreements containing hardcore restraints avoid proper assessment. Current regulation and the practice of Dutch courts do not contradict with the position of former chairman of the Netherlands Competition Authority, Pieter Kalbfleisch, who made a note regarding this when presenting his annual 2008 report: "We are certainly not blind to the difficult circumstances that undertakings are in right now, but it is not an excuse to conclude all kinds of illegal agreements" ${ }^{48}$. If the agreement contains such restraints, its current and potential impact on competition has to be assessed. Despite the crisis or other circumstances, the poor financial situation and related difficulties cannot be a reason for excuse.

Does it mean that the Netherlands will have trouble because the criteria for agreements that both contain and do not contain hardcore restraints do not differ? Does it contradict Article 101(1) of TFEU? It is assumed that the answer will depend only on the practice of national assessment institutions. Unquestionably national legal provisions do not contradict the practice of the ECJ. Nevertheless, the Commission's de minimis Notice should be considered as guidelines.

Imposing different quantitative criteria can help facilitate the work of institutions responsible for carrying out assessment. They can also take part in making the assessment of an agreement's impact on the competition process easier. Imposing different criteria also does not contradict the possibility to apply the rule of reason. The fact that the burden of proof is transferred to the parties of agreement helps to minimize the number of situations when the institutions responsible for carrying the assessment cannot complete the tasks set. It is important to have in mind that agreements containing hardcore restraints have been assessed before. As a rule the goals of those assessments were connected with determining the severity of sanctions.

Certainly the Netherlands were among the first ones to rehabilitate hardcore restraints in their legal acts by applying de minimis exemptions. In some EU member states such steps were made by jurisprudence. Spain's National Court (Audiencia Nacional) applied de minimis for agreement, containing a restriction by object. The Court abolished the resolution of National Competition Commission

48 Pieter Kalbfleisch, "Crisis geen vrijbrief voor verboden afspraken [Crisis is no Excuse for Illegal Agreements]," The 2008 Annual bulletin (January 28, 2009) // http://www.nmanet.nl (accessed June $10,2011)$. 
(Comision Nacional de la Competencia) in the case of MDC Ingenierka, S.L. against Haller Unweltsysteme GmbH \& Co. (HALLER), C.L.G. Haller S.A. (CLG), Vehkculos, Equipamientos y Carrocerka Prieto-Puga, S.L. (VEICAR) and Sociedade de Montagem y Automóveis (SOMA) ${ }^{49}$. Haller, the owner of know-how rights to specific waste treatment technologies in Germany, entered into technology licensing and transfer agreements with partners from Portugal and Spain. ${ }^{50}$ According to both agreements its parties received rights to produce and sell licensed products in Spain, Portugal and the former colonies of Iberian Peninsula. The participants of agreements imposed barriers for other undertakings to sell Haller's products in these territories. One of such undertakings, MDC, which activity was restricted, took legal action against the participants of these agreements.

The National Competition Commission determined that the goal of those agreements was the restriction of passive sales in territories outside of the field of distributors' activity. The terms of agreements were not covered by the exemption provided by European Commission's Regulation No. 772/2004 ${ }^{51}$. The National Competition Commission imposed an obligation for the agreement parties to pay a 356000 EUR fine and to refrain from the actions prohibited by legal acts. The anticompetitive provisions prohibited by national legal act provisions and also Article 81 of the Treaty establishing the European Community (currently Article 101 TFEU) on restricting passive sales by two licensing agreements, were declared. The National Competition Commission stated that the actions of the agreement parties were designed to make effective use of such clauses in order to prevent passive sales directed to Spanish territory ${ }^{52}$. The MDC, which took legal action against the agreements parties, felt the pressure to decline the part of business connected with Haller's production. Local authorities received documents ensuring them that the agreements' parties disclaim any liability arising from Haller products if the seller is a third party undertaking ${ }^{53}$.

The National Court abolished the resolution of the National Competition Commission of July 21, 2008, because this institution interpreted the facts incorrectly. According to the Court such activity is insufficient to restrict competition significantly. The imposed penalty was defined as a legal mistake. It is important

49 MDC Ingeniería/Productos Haller, Comision Nacional de la Competencia [National Competition Commission of the Kingdom of Spain] (2008, no. 634/07).

${ }^{50}$ Haller GMBh; Mercedes Pedraz Calvo, Audiencia Nacional [National Court of the Kingdom of Spain] (2009, no. 418/2008).

51 Regulation no. 772/2004 (April 27, 2004) on the application of Article 81(3) of the Treaty to categories of technology transfer agreements, European Commission, Official Gazette (2004, no. L 123). 52 Haller GMBh; Mercedes Pedraz Calvo, Audiencia Nacional [National Court of the Kingdom of Spain] (2009, no. 418/2008).

53 Annual Report 2007-2009, Comision Nacional de la Competencia // http://www.cncompetencia.es (accessed May 10, 2012), p. 165. 
that the Court took into account Hallers' arguments that the market share of this economic unit is less than five percent in Europe and Spain.

Of course this National Court resolution has reasonably caused controversial opinions. ${ }^{54}$ The spreading of de minimis exemption should be considered a positive step but all together as everything else it has to be reasonable. According to critics the National Court took into account only quantitative markets share criteria without a deeper economic analysis. In that way a step was made from one extremity to another: from unconditional denial of de minimis for such agreement to its application because of the quantitative criteria not being exceeded. In each case an individual assessment of agreement has to be conducted. The Court created a precedent which, at least in the near future, will be obligatory for the National Competition Commission to take into account. The Court's decision determining impact on competition through quantitative criteria (shares in relevant market) abolished the difference in assessment criteria between agreements containing hardcore restraints and those without them.

The European Commission's de minimis Notice does not impose obligations for the ECJ and national legal authorities to follow provided criteria. The Notice by its nature and juridical power is recommendatory. The institutions responsible for carrying out assessment retain the right to carry economic analysis of the agreement independently and to determine if the agreement restricts competition significantly or not. The Spanish court relied on de minimis Notice quantitative criteria.

The application of de minimis exemption could also be found in the practice of some other states as well. For example, in Germany, where the court stated that small (having less than 1 percent share in relevant market) economic units cannot restrict competition significantly ${ }^{55}$. There is no doubt such jurisprudence should become a signal for national legislation, as it already happened in the Netherlands. At the moment the only justification for the delay is waiting for certain actions from the European Commission. The Netherlands example can definitely be considered a successful one. The main tasks would be to avoid the "Spanish mistakes" (formal assessment in accordance with quantitative criteria) and to conduct the economic analysis on the impact on competition.

\footnotetext{
${ }^{54}$ Garrigues Antitrust Newsletter No. 18 (December 2009) // http://www.garrigues.com/es/Publicaciones/Newsletters/Documents/Antitrust_Newsletter_18_en_29122 009170534.pdf (accessed June 10, 2011).

55 Petra Linsmeier and Moritz Lichtenegger, "The German Higher Regional Court of Düsseldorf holds that hardcore restrictions are not per se appreciable if the relevant market share is below $1 \%$ (Tschechisches Bier)," e-Competitions No. 21232 (June 23, 2004) // www.concurrences.com (accessed June 10, 2011).
} 
Is de minimis exemption applicable for agreements containing hardcore restraints in Lithuania? National practice analysis ${ }^{56}$ implies a negative answer. The Competition Council has not applied this exception for agreements containing restraints by object. Despite the conducted analysis of agreements' impact on competition, the possibility to rehabilitate such agreements is automatically abolished. The reason is current EU regulation. Almost all of the Competition Councils resolutions ${ }^{57}$ where price-fixing restraint was determined state that the practice concerned with fixing the prices directly or indirectly is determined as restricting competition by object. According to current practice there is no need to determine anticompetitive impact of such concerned practices. Exceptions should not be applied as well. It seems that during the assessment process the market shares of participants of hardcore restricted agreements for Competition Council are not important. Even the smallest share in a relevant marked does not grant the right to expect application of de minimis exemption.

The generalization of the Competition Council's practice leads to the conclusion that the fate of each agreement is decided after determining whether it contains hardcore restraints or not. The latter option allows checking the possibility to apply de minimis exception. The first one does not permit even raising such a question. The reason is simple: national legislation does not provide for such a possibility. Nevertheless, such criticism is unreasonable because the Competition Council has not had access to situations where agreements containing hardcore restraints had no significant impact on competition yet.

Despite the lack of national practice, when agreements from the blacklist would be prohibited regardless of their insignificant impact on competition, current regulation requires it to be amended. The situation when legal acts do not grant the possibility to apply an exception for agreements containing hardcore restraints is temporary. National practice should change after the European Commission broadens de minimis application. Bearing in mind legal specialists' suggestions and the practice of some member states, it is safe to say that the process has already started.

\section{CONCLUSIONS AND PROPOSALS}

1. Despite the fact that legislators do not rush to rehabilitate agreements containing hardcore restraints, such steps were made by the ECJ and a few national courts. This practice should lead to amendments in the legislation. Competition

\footnotetext{
56 The source is accessible at http://www.konkuren.It.

57 For instance Resolution no. 2S-10 (May 12, 2011), Competition Council of the Republic of Lithuania, Official Gazette (2011, no. 39(1)-353).
} 
Council of Lithuania does not have such precedents - de minimis exemption has not been applied for agreements containing hardcore restraints. The agreements containing restraints by object are prohibited per se. Against this background the practice of the Netherlands inspires optimism. The amendment of their national competition act of 2010 allows applying de minimis exemption for hardcore restricted agreements. This reform is a significant step forward. Nevertheless, the success of it depends on the practice of institution which will carry out the assessment.

2. If the market shares of agreement parties are small, the existence of a cartel is considered to be fragile and lifeless. Its participants would break agreements on any convenient occasion. The market itself is capable of deciding the fate of such cartels.

3. Attempts to rehabilitate agreements containing hardcore restraints through jurisprudence are welcome; however, they cannot be supported only by presumptions and comparison of the agreements' provisions and criteria from legal acts, and precedents. The decision of Spain's National Court in the Hallers case ${ }^{58}$ should be considered as a step forward, but it also deserves some criticism. The court applied de minimis exemption for agreement containing hardcore restraint without economic assessment of its impact on competition. In each case an individual assessment must be conducted.

4. The number of suggestions to strike out some restraints from the blacklist of de minimis Notice has increased. It is more frequent for restraints that arise from vertical agreements. It is better for the exemplary list to stay untouched, but the agreements containing such restraints should be assessed in accordance with stricter criteria. The application of de minimis exemption should not be abolished unless the agreement's impact on competition is significant. Legal acts should provide different quantitative criteria for agreements containing hardcore restraints and the ones without them. For example, it could be current ten percent for horizontal and mixed agreements and fifteen percent for vertical ones. If the agreement contains hardcore restraints the market shares could be 1-1.5 percent depending on the agreement. Of course the exact numbers still have to be evaluated by specialists in economics.

5. The per se rule deserves more criticism because of its inflexibility. Also there have been frequent suggestions (for example, by prof. L. Tichý) to conduct analysis based on an economic model, reflected by individual assessment of specific agreement. Such reforms would be useful when seeking to avoid the inflexible formal assessment as well as unreasonable application of Article 101(1) of TFEU for

${ }^{58}$ Haller GMBh; Mercedes Pedraz Calvo, supra note 50. 
agreements that do not impose significant restraints on competition. A narrower rule of reason doctrine is the suggested alternative.

\section{BIBLIOGRAPHY}

1. Annual Report 2007-2009. Comision Nacional de la Competencia // http://www.cncompetencia.es (accessed May 10, 2012).

2. "Beware of legal privilege?! Dutch de minimis exemption for hardcore infringements in line with EU law." Competition Newsletter, De Brauw Blackstone Westbroek (February 2011) //

http://www.debrauw.com/SiteCollectionDocuments/Legal\%20Alerts/Competiti on/Competition\%20Newsletter\%20February\%202011.html (accessed June 15, 2011).

3. Drexl, Josef, Laurence Idot, and Joel Maneger. Economic Theory and Competition Law. Academic Society for Competition Law (ASCOLA). Edward Elgar Publishing Limited, 2009.

4. Garrigues Antitrust Newsletter No. 18 (December 2009) // http://www.garrigues.com/es/Publicaciones/Newsletters/Documents/Antitrust _Newsletter_18_en_29122009170534.pdf (accessed June 10, 2011).

5. Jones, Alison, and Brenda Sufrin. EU Competition Law. Text, Cases, and Materials. Fourth Edition. New York: Oxford University Press, 2011.

6. Jones, Alison. "The Journey Toward an Effects-based Approach under Article 101 TFEU - The Case of Hardcore Restraints." The Antitrust bulletin Vol. 55, No. 4 (Winter 2010): 783-818.

7. Kalbfleisch, Pieter. "Crisis geen vrijbrief voor verboden afspraken" [Crisis is no Excuse for Illegal Agreements]. The 2008 Annual bulletin (January 28, 2009) // http://www.nmanet.nl (accessed June 10, 2011).

8. Kjølbye, Lars. "Escaping Effects Analysis: The Commission's New Approach to Restrictions by Object." CPI Antitrust Journal: Covington \& Burling LLP (2011 (1)).

9. Linsmeier, Petra, and Moritz Lichtenegger. "The German Higher Regional Court of Düsseldorf holds that hardcore restrictions are not per se appreciable if the relevant market share is below $1 \%$ (Tschechisches Bier)." $e$ Competitions No. 21232 (June 23, 2004) // www.concurrences.com (accessed June 10, 2011).

10. Ritter, Lennart, and David W. Braun. European Competition Law: A Practitioner's Guide. Third Edition. Kluwer Law International, 2004. 
11. Švirinas, Daivis. "The Peculiarities of the Assessment of the Use of Recommended Resale Prices under Article 81 of the European Community Treaty." Social Sciences Studies No. 1(5) (2010): 219-236.

12. Van Bael \& Bellis. Competition Law on the European Community. Kluwer Law International, 2005.

13. Verras, Nikolaos. "Developments in Vertical Agreements." The Antitrust bulletin Vol. 55, No. 4 (Winter 2010): 843-874.

14. Verras, Nikolaos. "Resale Price Maintenance in E.U. Competition Law: Thoughts in Relation to the Vertical Restraints Review Procedure." The Columbia Journal of European Law Online 37 (2009) // http://www.cjel.net/online/16_1-verras/ (accessed June 10, 2011).

15. Whish, Richard. Competition Law. Sixth Edition. New York: Oxford University Press, 2009.

\section{LEGAL REFERENCES}

1. Communication (January 14, 2011) on Guidelines on the Applicability of Article 101 of the Treaty on the Functioning of the European Union to Horizontal Co-operation Agreements. European Commission. Official Gazette, 2011, no. C 11/01.

2. Competition Authority v. Beef Industry Development Society Ltd and Barry Brothers (Carrigmore) Meats Ltd. European Court of Justice, 2008, no. C209/07.

3. Consolidated Version of the Treaty on the Functioning of the European Union. Official Gazette, 2008, no. C 115/47.

4. European Night Services v. Commission. The Court of First Instance, 1998, Case T-374/94.

5. General Motors BV v. Commission of the European Communities. European Court of Justice, 2006, no. C-551/03.

6. Guidelines (May 19, 2010) on Vertical Restraints. European Commission. Official Gazette, 2010, no. C 130/01.

7. Haller GMBh; Mercedes Pedraz Calvo. Audiencia Nacional [National Court of the Kingdom of Spain], 2009, no. 418/2008.

8. ICI v. Dyestuffs (Commission). European Court of Justice, 1972, no. 48/69.

9. Law on Competition of the Kingdom of the Netherlands. 1997 [with amendments which entered into force after July 1, 2009] // http://www.dutchcivillaw.com/legislation/competitionact.htm (accessed June 10, 2011). 
10. Law on Competition of the Republic of Lithuania. Official Gazette, 1999, no. 30-856.

11. MDC Ingeniería/Productos Haller. Comision Nacional de la Competencia [National Competition Commission of the Kingdom of Spain], 2008, no. 634/07.

12. Notice (December 22, 2001) on agreements of minor importance which do not appreciably restrict competition under Article 81(1) of the Treaty establishing the European Community (de minimis). European Commission. Official Gazette, 2001, no. 368/07.

13. Notice (December 9, 1997) on the definition of relevant market for the purposes of Community competition law. European Commission. Official Gazette, 1997, no. 372/03.

14. Regulation no. $1 / 2003$ (December 16, 2002) on implementation of the rules on competition laid down in Articles 81 and 82 of the Treaty. European Council. Official Gazette, 2003, no. L 1.

15. Regulation no. 772/2004 (April 27, 2004) on the application of Article 81(3) of the Treaty to categories of technology transfer agreements. European Commission. Official Gazette, 2004, no. L 123.

16. Resolution no. 17 (February 24, 2000) Concerning Explanations of the Competition Council on the Definition of the Relevant Market. Competition Council of the Republic of Lithuania. Official Gazette, 2000, no. 19-487.

17. Resolution no. 1S-172 (December 9, 2004) on Approval of Requirements and Conditions in Respect of Agreements of Minor Importance which do not Appreciably Restrict Competition. Competition Council of the Republic of Lithuania. Official Gazette, 2004, no. 181-6732.

18. Resolution no. 2S-10 (May 12, 2011). Competition Council of the Republic of Lithuania. Official Gazette, 2011, no. 39(1)-353.

19. T-Mobile Netherlands BV, KPN Mobile NV, Orange Nederland NV, Vodafone Libertel BV v. Raad van bestuur van de Nederlandse Mededingingsautoriteit. European Court of Justice, 2009, no. 8/108.

20. Völk v. Vervaecke. European Court of Justice, 1969, no. 5/69. 